\title{
ANALISIS WARNA CAHAYA LAMPU TERHADAP HASIL TANGKAPAN IKAN
}

\author{
GRACE LOUPATTY \\ Staf Jurusan Fisika FMIPA UNPATTI \\ J1. Ir. M. Putuhena, Kampus Unpatti, Poka-Ambon \\ e-mail: grace_loupatty@yahoo.com
}

\begin{abstract}
By learning and researching the wave-length of light and its propagation we can make an observation of the function and effectiveness light as a stimulation in fishing.

The purposes of the observation are: to know how the color of light lamp influences to the result of fishing; to observe how the depth of location for fishing influences the reduction of light intensity; to know what is the relation between parameter condition/ atmosphere (salinity, temperature and transparency of the water) with the result of fishing.

The observation is applied with a direct observation method in water of Batu Dua- Ambon Island.

The total result of fishing is 57.2 kilograms with applied for us different light lamp (red, yellow, green and blue). Each color applied has the result: the red light lamps got amount of $4.5 \mathrm{~kg}$; the yellow light lamps got amount of $15,1 \mathrm{~kg}$; the green light lamps got amount $17.4 \mathrm{~kg}$; and the blue light lamps got amount of $20.2 \mathrm{~kg}$.

Data analysis statistically using an analysis of variance system which indicates that the stimulation light lamp influences to the result of fishing.

Result of the statistical observation shows that parameter conditions/ atmosphere in the water, such as salinity. temperature, transparency of the water, such as: salinity, temperature, transparency of the water do not influence to the result of fishing.
\end{abstract}

Keywords: Light lamp, fishing, analysis of variance

\section{PENDAHULUAN}

\section{Latar Belakang}

Laut merupakan bagian terbesar dari luas kepulauan Indonesia sebesar 90\%. Selain sebagai alat pemersatu yang menghubungkan berbagaipulau di Indonesia, laut juga merupakan sumber perikanan yang berpotensial tinggi. Dalam penangkapan ikan terdapat penggunaan berbagai pengetahuan dasar (basic sciences) serta pengetahuan terapan (applied scienes) seperti: fisika, biologi, ekologi, oceanografi, meteorlogi dan klimatologi, elektronika, mesin dan lain-lain (Ayodhyoa, 1981).

Cahaya merupakan topik penting yang dipelajari dalam fisika dan juga merupakan faktor penting dalam operasi penangkapan ikan. fungsi daripada cahaya yaitu untuk menarik ikan-ikan berkumpul ke suatu tempat dimana sumber cahaya itu berasal supaya memudahkan penangkapan. Pemanfaatan warna dari lampu pemikat serta pengaturannya sangat penting untuk keberhasilan penangkapan.

\section{Tujuan}

Penelitian ini bertujuan untuk :

1. Mengetahui pengaruh penggunaan warna cahaya lampu pemikat terhadap hasil tangkapan

2. Mengetahui pengaruh kedalaman terhadap pengaruh kedalaman terhadap pengurangan itensitas cahaya

3. Mengetahui hubungan antara parameter lingkungan seperti salinitas, suhu dan kecerahan dengan hasil tangkapan.

\section{TINJAUAN PUSTAKA}

\section{Cahaya}

Teori Maxwell menyatakan bahwa cahaya menyebar dalam bentuk gelombang elektromagnetik. Kecepatan cahaya sekitar $3 \times 10^{8} \mathrm{~m} / \mathrm{s}$. Panjang gelombang cahaya tampak berkisar antara $390 \mathrm{~nm}$ sampai $780 \mathrm{~nm}$ dan frekuensinya sekitar $3.84 \times 10^{14} \mathrm{~Hz}$ sampai $7.69 \times 10^{14} \mathrm{~Hz}$ (Hecht and Zajac, 1976). 
Jika dA adalah luas dari sudut permukaan yang normalnya membentuk suatu $\Theta$ dengan jarak $\mathbf{r}$ ke suatu sumber $\mathbf{S}$, dan $\mathbf{I}$ adalah intensititas cahaya dari sumber $\mathbf{S}$ pada arah yang menuju dA, maka :

dimana

$$
\begin{aligned}
& \mathrm{dF}=\mathrm{Id} \omega=\frac{\mathrm{IdA} \cos \theta}{\mathrm{r}^{2}} \\
& \mathrm{E}=\frac{\mathrm{dF}}{\mathrm{dA}}=\frac{\mathrm{I} \cos \theta}{r^{2}}
\end{aligned}
$$

E adalah iluminasi cahaya pada unsur luas dA

$\mathrm{dF}$ adalah fluks cahaya yang mengenai $\mathrm{dA}$

Satuan dari iluminasi cahaya adalah lumen $/ \mathrm{m}^{2}$ atau disebut juga lux (Sears, 1956).

\section{Cahaya Dalam Air}

Cahaya dari sebuah sumber di udara mengenai permukaan air, ada yang diteruskan, ada yang dipantulkan, ada yang dihamburkan, dan ada yang diserap. Pemantulan ini tergantung pada sudut dating sinar dn keadaan perairan (Yami, 1987).

Jumlah cahaya yang hilang karena serapan, hamburan dan pemantulan dikenal sebagai "total extinction", yang dinyatakan dengan koefisien "extinction" (k). Menurut Tait (1981), dengan menggunakan ckram Secchi, koefisien extinction (k) dirumuskan dengan persamaan:

$$
\mathrm{K}=\frac{1.45}{d}
$$

dimana d adalah kedalaman maksimum cakram secchi kelihatan

\section{Penggunaan Lebagai Sumber Cahaya dalam Penangkapan Ikan}

Dalam light fishing, penangkapan ikan dilakukan dengan memanfaatkan salah satu kelakuan ikan (phototaxis) untuk menangkap ikan itu sendiri (Ayodhyoa, 1981).

Sumber cahaya yang umum dipergunakan untuk memikat ikan pada saat ini adalah lampu tekan minyak tanah dan lampu listrik. Faktor-faktor yang mempengaruhi penyebaran cahaya yang menembus ke dalam air yaitu: (1) sifat alamiah cahaya matahari atau bulan; (2) kapasitas partikel yang terkandung di dalam air; (3) kapasitas cahaya yang dipantulkan oleh permukaan lain, maupun partikel-partikel air (Verheyen dalam Kristjonson, 1959).

\section{ALAT DAN METODE PENELITIAN}

\section{Alat}

Alat yang digunakan dalam penelitian ini adalah:

a. Lampu empat warna (merah, kuning, hijau, biru), masing-masing warna terdiri dari empat tipe bereflektor dengan kekuatan masing-masing 60 watt, dan empat tipe fluorescent dengan kekuatan masing-masing 10 watt.

b. AC Generator model FA-2; 1 phase dengan output $2 \mathrm{kVa}$

c. Refractometer (salinity type);

d. Thermometer

e. Cakram Secchi

f. Bagan (17m x 17m); jarring ( $19 \mathrm{~m} \times 17 \mathrm{~m} \times 15 \mathrm{~m})$

g. Scoop net

\section{h. Timbangan}

\section{Metode Penelitian}

Penelitian ini dilakukan dengan cara percobaan langsung dilapangan, dengan empat warna lampu ( merah, kuning, hijau, biru) sebagai perlakuan yang masingmasing diulang sebanyak tiga kali. Tiap perlakuan berlangsung selama empat jam.

Data yang diambil pada tiap perlakuan meliputi pengukuran parameter lingkungan (salinitas, suhu, kecerahan dan pengukuran hasil tangkapan ikan).

Penelitian dilaksanakan dilokasi perairan Batu Dua Pulau Ambon.

\section{HASIL DAN PEMBAHASAN}

Hasil tangkapan yang diperoleh dari perlakuan yang diberikan selama penelitian diuji secara statistik (analisis ragam). Pada tabel 1 ditunjukkan bahwa analisis ragam hasil tangkapan dengan perlakuan warna cahaya berbeda nyata.

\begin{tabular}{|c|c|c|c|c|c|}
\hline $\begin{array}{l}\text { Sumber } \\
\text { ragam }\end{array}$ & $\mathrm{db}$ & $\mathrm{Jk}$ & KT & $\mathrm{F}_{\text {hit }}$ & $\begin{array}{l}\mathrm{F}_{\mathrm{Tab}} \\
5 \%\end{array}$ \\
\hline Blok & 2 & 207768.1 & 103884.0 & 0.208272 & 5.14 \\
\hline Perlakuan & 3 & 47181985 & 15727328 & 31.53094 & 4.76 \\
\hline Error & 3 & 2992741 & 498790.1 & & \\
\hline Total & 11 & 50382741 & & & \\
\hline
\end{tabular}

Tabel 1. Analisis ragam hasil tangkapan ikan dengan perlakuan warna cahaya.

$\mathrm{CV}=14.83278 \%$

Perbedaan nyata ini ditunjukkan oleh perlakuan yang lebih besar dari $\mathrm{F}_{\text {Tabel }} 5 \%$.

Hasil tangkapan yang diperoleh dalam penelitian ini sebesar $57.2 \mathrm{~kg}$, yang diperoleh dari total perlakuan warna cahaya lampu (merah, kuning, hijau, biru), dengan perincian untuk masing- masing warna adalah sebagai berikut: (a) untuk perlakuan warna merah dengan hasil tangkapan sebesar $4.5 \mathrm{~kg}$; (b) warna kuning dengan hasil tangkapan sebesar $15.1 \mathrm{~kg}$; (c) warna hijau dengan hasil tangkapan sebesar $17.4 \mathrm{~kg}$; dan (d) warna biru dengan hasil tangkapan sebesar $20.2 \mathrm{~kg}$.

Tabel 2. Rerata Hasil Tangkapan Ikan (g) dengan warna lampu merah, kuning, hijau, biru.

\begin{tabular}{|c|lc|}
\hline Perlakuan (warna lampu) & \multicolumn{2}{|l|}{ Hasil Tangkapan $(\mathrm{g})$} \\
\hline Merah & 1493.33 & $\mathrm{c}$ \\
Kuning & 5023.33 & $\mathrm{~b}$ \\
Hijau & 5785.00 & $\mathrm{ab}$ \\
Biru & 6744.00 & $\mathrm{a}$ \\
\hline
\end{tabular}

Keterangan : Angka-angka yang diikuti dengan huruf yang sama, tidak berbeda nyata menurut uji jarak berganda Duncan pada taraf 5\%.

Hasil analisis pada tabel 2. Menunjukkan bahwa pengaruh perlakuan lampu warna biru memberikan tangkapan tertinggi dan diikuti berturut-turut oleh warna hijau, warna kuning dan warna merah.

Dari rerata hasil yang didapatkan menunjukkan bahwa warna cahaya lampu yang terbaik dalam mengkonsentrasikan ikan adalah warna biru dan warna 
hijau. Cahaya warna biru paling sedikit terabsorbsi air laut dan lebih dominan dibiaskan oleh partikel dalam air. Nilai koefisien k tergantung pada suhu dan salinitas. Oleh karena itu intensitas sinar yang terdapat di air laut pada kedalaman tertentu akan berbeda. Ini disebabkan oleh adanya suspense dalam air laut yang mempunyai sifat selektif. Ditambahkan pula bahwa semakin kecil atau semakin pendek panjang gelombang suatu warnacahaya berarti semakin besar pengaruh rangsangan terhadap ikan. Cahaya hijau dengan panjang gelombang 500nm mempunyai transmisi sebesar 905 per meter, cahaya kuning dengan panjang gelombang $600 \mathrm{~nm}$ transmisinya sebesar $80 \%$ per meter, cahaya warna merah mempunyai panjang gelombang sebesar 650nm dengan transmisi sebesar $60 \%$ per meter. Lampu warna biru memperlihatkan hasil tangkapan yang lebih baik. Hal ini didukung oleh pendapat Nomura dan Yamazaki (1975) yang mengemukakan bahwa secara alamiah ikan-ikan lebih tertarik pada berkas cahaya warna biru dan hijau daripada warna lainnya. Ditambahkan pula oleh Yami (1987) bahwa warna biru dan warna hijau mempunyai kemampuan penetrasi yang lebih jauh ke dalam air jika dibandingkan dengan warna-warna yang lain, karena kurang diserap oleh partikel-partikel di dalam air. Kemampuan penetrasi yang dimiliki oleh warna biru dan hijau memungkinkan ikan-ikan yang berada pada jarak yang jauh, baiik secara vertikal maupun horizontal terpikat dan datang mendekati atau menuju arah datangnya cahaya tersebut.

Untuk pengurangan intensitas cahaya terhadap kedalaman menurut hasil analisis ragam tidak dipengaruhi oleh warna cahaya lampu yang digunakan.

Parameter lingkungan yang diamati : salinitas pada lokasi lokasi penelitian berkisar $27.5 \%$ \% $-35 \%$; suhu berkisar $27^{0} \mathrm{C}-29^{\circ} \mathrm{C}$; kecerahan perairan berkisar dari 10-20m. Hasil uji statistik dengan analisis regresi linier majemuk menunjukkan bahwa parameter lingkungan selama penelitian tidak berpengaruh terhadap hasil tangkapan. Ini menunjukkan bahwa parameter lingkungan selama penelitian tidak berpengaruh terhadap hasil tangkapan. Ini menunjukkan bahwa besarnya kisaran dari parameter lingkungan tersebut masih dalam toleransi aktifitas hidup ikan-ikan hasil tangkapan. Dengan analisis regresi linier majemuk untuk perlakuan warna cahaya lampu menunjukkan bahwa lampu warna kuning mampu menangkap ikan 3614 kali disbanding merah; lampu warna hijau mampu menangkap ikan 3711 kali disbanding warna merah; dan warna biru mampu menangkap 5112 kali dibandingkan lampu warna merah. Cahaya lampu, intensitas, warna lampu, cuaca, penyebaran cahaya, lama waktu penyinaran, cahaya bulan, merupakan faktor-faktor yang mempengaruhi terhadap hasil tangkapan (Najamuddin dkk,1994 dalam Sudirman dan Mallawa, 2004). Secara alamiah ikan-ikan lebih tertarik pada berkas cahaya biru dan hijau daripada warna lainnya (Nomura dan Yamazaki, 1975). Warna biru dan hijau mempunyai kemampuan penetrasi yang lebih jauh ke dalam air jika dibandingkan dengan warna- warna lain (Yami, 1987).

\section{KESIMPULAN}

Warna cahaya lampu memberikan pengaruh yang berbeda terhadap hasil tangkapan. Cahaya lampu warna biru menghasilkan tangkapan terbesar dan diikuti berturut- turut oleh warna hijau, kuning dan merah.

\section{SARAN}

Perlu penelitian lebih lanjut untuk mengetahui kapasitas atau besar daya lampu yang paling efektif terhadap hasil tangkapan, khususnya untuk berkas cahaya lampu warna biru dan hijau sebagai berkas lampu yang memberikan hasil tangkapan terbesar.

\section{DAFTAR PUSTAKA}

Ayodhyoa, 1981, Metoda Penangkapan Ikan, Yayasan Dewi Sri. Bogor.

Hecht, E. dan Zajac, A., 1976, Optics, Third ed. Addison Wesley Publishing Company, Inc, Philippines.

Kristjonson, H., 1959, Modern Fishing Gear of The World, Volume I. Fishing News Books (Ltd). London.

Nomura dan Yamazaki, 1975, Fishing Techniques, Japan International Corporation Agency - JICA.

Sudirman dan Mallawa, 2004, Teknik Penangkapan Ikan. Rineka Cipta, Jakarta

Tait, R.V., 1981, Elements of Marine Ecology-An Introductory Course, Butterworths. London.

Yami, B., 1987, Fishing With Light, Fishing News Books (Ltd), London 